Subscription in India and abroad Rupees 16 per annum. Post free. Payable in advance

THE INDIAN

JOURNAL OF MEDICAL RESEARCH

Edited by THE DIRECTOR-GENERAL, INDIAN MEDICAL SERVICE, THE PUBLIC HEALTH COMMISSIONER WITH THE GOVERNMENT OF INDIA, and THE DIRECTOR, CENTRAL RESEARCH INSTITUTE, in collaboration with LEADING AUTHORITIES ON TROPICAL MEDICINE. The Indian Journal of Medical Research is published quarterly. Each number contains about 200 pages and is illustrated with Plates in Colout and Half-tone and with Diagrams and Charts, and is the only medium publishing the results of the best medical research work being carried on by leading scientific medical men in India and the East.
THACKER, SPINK \& CO.
(P.O. BOX 54)

LONDON AGENTs: W. Thacker \& Co., 2, Creed Lane, E.C. 4.

\title{
The Comparative Physiology of Internal Secretion
}

By LANCELOT T. HOGBEN, M.A. (Cantab.), D.Sc. (Lond.)

With 37 illustrations. Demy 8vo. 10s. $6 d$. net

Cambridge Comparative Physiology

This is the third volume of the new series dealing with comparative physiology, which the Cambridge University Press has recently started.

CAMBRIDGE UNIVERSITY PRESS, FETTER LANE, LONDON, E.C.4

\section{The Quarterly Journal of Medicine}

\section{Edited by}
T. R. ELLIOTT
W. HALE-WHITE
F. R. FRASER
R. HUTCHISON
A. E. GARROD
H. D. ROLLESTON

with the help of

J. Hill Abram

Byrom Bramwell

John Cowan

David Drummond

T. Wardrop Griffith

G. Lovell Gulland
Arthur J. Hall

Gordon Holmes

Arthur F. Hurst

J. A. Lindsay

H. Maclean

George R. Murray
J. A. Nixon

R. W. Philip

E. P. Poulton

E. I. Spriggs

A. M. Stalker

R. Stockman

SINGLE NUMBERS $10 s .6 d$. NET EACH

VOLUMES - - 45s. NET

SUBSCRIPTION - 35 s. PER ANNUM 


\section{CONTENTS}

(All rights reserved)

Grmprin, Fred. The Significance of Pneumoeoceal Types . . . 113

Dudgeon, Leonard S. and Snrpson, J. W. Hope. On the Differentiation of the Staphylococci, with Special reference to the Precipitin Reactions

MoKnntay, Pener L. The Proportional Frequency of General Paralysis of the Insane and Locomotor Ataxia in different Social Classes.

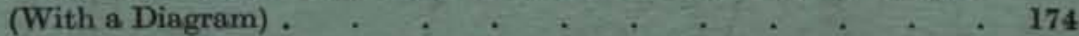

BAKER, JoHN R. The Influence of High Temperstures on the Testis . 183

MoKrniay, Pexwe L. The Relation between Puerperal Septicaemia and certain Infectious Diseases. (With 3 Diagrams) . . . .

Orer, J. B., Godden, W. and Densdas, J. M. Iodine in Drinking Waters . . . . . . . . . . . . .

Wrrmrne, C. H. On the Identification of Pneumococoi and the Tests employed for distinguishing them from Streptococci. . . . .

Matmok, A. T. R. and Procrer, F. The Production of Milk of Low Bacterial Content by means of Milking Machines. (With 1 Textfigure)

The Journal of Hygiene is issued as material accumulates. A volume containing four numbers is issued annually in paper covers at the following net prices:

Volumes I-III (1901-3). 17s, 6d.

VolumesIV-XVI(1904-18), exceptingVol.VI, no. 4, Plague number. $25 s$. Volume XVII (1918). 31 s.

Volumes XVIII-XXVI (1919-1927). 42s. each.

Quotations can be given for buckram binding cases and for binding subscribers' sets; also for bound copies of back volumes.

Papers for publication may be sent to Prof. GEo. H. F. Nutrall, F.R.S., Longfield, Madingley Road, Cambridge, or to the associate Editors. Other communications should be addressed to the University Press, Cambridge.

Papers forwarded to the Editors for publication are understood to be offered to The Journal of Hygiene alone, unless the contrary is stated.

Contributors receive fifty copies of their papers free. Additional copies may be had at cost price: these should be ordered when the final proof is returned.

The subscription price is \$2. 2s. per volume (post-free), payable in sdvance; single numbers $128.6 d$. net. Subscriptions may be sent to any Bookseller, or to The Cambridge University Press, Fetter Lane, London, E.C. 4.

The Cambridge University Press has appointed the University of Chicago Press agents for the sale of The Journal of Hygiene in the United States of America and has authorised them to eharge the following prices: Subseription $\$ 10.00$ per volume; single numbers, $\$ 3.00$ each.

Plague Numbers, Vol. VI. no. 4 (out of print), Vol. VII. nos. 3 and 6 , and Vol. VIII. no. 2, Vol. X. no. 3, Price $6 s$. net each.

A series of Plague Supplements has been issued; the first four of these contain Reports VI-IX on Plague Investigations in India. They are, in pagination, completely independent of the Journal although subscribers to the latter receive copies without extra cost. Price of Plague Supplements, i. and i1. 7s. net each; iii. 10s. net; iv. and v. 7s, net each. Plague Supplements i, ii, iii can also be supplied bound in buckram, price 20 s. net. 